\title{
THE EFFECT OF COOPERATIVE LEARNING MODEL OF TEAM GAME TOURNAMENT (TGT) TYPE ON STUDENTS' MATHEMATICAL LEARNING ACHIEVEMENT OF JUNIOR HIGH SCHOOL
}

\author{
Muhammad Arifuddin*, Laila Hayati, Amrullah, and Baidowi \\ Mathematics Education Department, FKIP University of Mataram, Mataram, Indonesia \\ *Email: muhammad.arifuddin090397@gmail.com
}

Accepted: July, 31 2021. Approved: August, 31 2021. Published: November, 112021

\begin{abstract}
This research aims to find out the effect of cooperative learning models of the Teams Games Tournament (TGT) type on the students' mathematics learning achievement of the 8th-grade students of SMPN 13 Mataram Academic Year 2019/2020. This study is a quasi-experimental with the post-test only nonequivalent control group design type. The population of the research was the whole 8th-grade students of SMPN 13 Mataram Academic Year 2019/2020. In determining the sample, probability sampling was being used in the of form cluster random sampling, the sample of the research was the VIII-A class as the experimental class and VIII-B class as the controlling class. The instrumen which was used in this research was the test of the students learning achievement (post-test). Quantitave analysis obtained by using t-test. The results of this research showed that there were differences in students learning outcomes with the TGT type cooperative model and direct learning model students. By the effect size method, we obtain that the effect of TGT type on the student's achievement was high category. Furthermore, that's mean that TGT type can be given a high effect on students' achievement in the concept of linear equation system for two variables. For teachers, especially in SMPN 13 Mataram should be an alternative learning model of the TGT cooperative model as an one of the next mathematics learning.
\end{abstract}

KeyWords: Cooperative Learning Model, Teams Games Tournament, Mathematics Learning Achievement.

\section{INTRODUCTION}

The development of science and technology allows all parties to obtain information abundantly, quickly and easily from various sources. Therefore, mastery of mathematics material for students is a necessity that cannot be negotiable in structuring reasoning and decision making in the era of increasingly competitive competition at this time. Students need to have the ability to obtain, select and process information to survive in an ever-changing, uncertain and competitive situation. This ability requires critical, systematic, logical, creative thinking and effective collaboration. This way of thinking can be developed through learning mathematics, because mathematics has a strong and clear structure and linkage between concepts so that it allows students to be skilled at rational thinking [1].

The purpose of learning mathematics according to the 2013 curriculum [2], emphasizes the modern pedagogic dimension in learning, namely using a scientific approach. In learning mathematics, the activities carried out for meaningful learning are observing, asking, trying, reasoning, presenting and creating.

All the abilities stated above are expected to be possessed by students. However, it cannot be realized if it only relies on the learning process that has been used to exist in schools, such as teaching by being taught theories/definitions/theorems, then giving examples and finally being given practice questions [3].
Given that mathematics is a subject that is used as a graduation requirement, mathematics should be one of the subjects that must be mastered by students at school. However, in reality many students find it difficult in these subjects. A similar situation also occurred at SMPN 13 Mataram, where the mathematics ability of grade VII students was still low. This can be seen from the average end-of-semester test score (UAS) for mathematics subjects in the even semester of the 2018/2019 school year which is still below the KKM set by the school, which is 75 . For more details, see Table 1 below.

Table 1 Data on Even Semester Final Exam Results for Class VII Students at SMPN 13 Mataram 2018/2019 Academic Year

\begin{tabular}{|c|c|c|c|}
\hline No. & Class & Total students & $\begin{array}{c}\text { Average } \\
\text { value }\end{array}$ \\
\hline 1 & VII-A & 33 & 64,97 \\
\hline 2 & VII-B & 34 & 62,91 \\
\hline 3 & VII-C & 34 & 67,08 \\
\hline 4 & VII-D & 34 & 66,58 \\
\hline 5 & VII-E & 26 & 62,96 \\
\hline 6 & VII-F & 27 & 67,74 \\
\hline 7 & VII-G & 27 & 66,81 \\
\hline 8 & VII-H & 26 & 64,84 \\
\hline 9 & VII-I & 27 & 66,77 \\
\hline
\end{tabular}

(Source: List of Grade VII Mathematics Teacher Grades at SMPN 13 Mataram for 2018/2019 Academic Year) 
Based on the results of observations and interviews conducted on July 31, 2019 with class VII students and teachers of SMPN 13 Mataram, it was found that there are several things that are suspected to be the cause of the low learning outcomes of mathematics, namely students tend to be less cooperative with each other, if there are difficulties students tend to silent on the teacher, if someone asks only certain students, the teacher still looks more dominant than the students so that students feel bored quickly and less active in following the learning process, because the flow of information only goes one way, namely from the teacher to the students In addition, there is also a lack of motivation or encouragement from within the students themselves to learn. Many students are afraid to ask questions, even though the teacher often asks students to ask questions if there is something they don't understand. However, on the other hand, when learning takes place, students are more likely to talk to their friends when there are things that have not been understood from the teacher's explanation.

Based on this, it is necessary to have a learning that is able to facilitate students' discussions with the aim of further increasing student interaction which initially only with their classmates will develop into interaction with groups. This will indirectly increase student activity in the learning process.

The learning model that is suitable for facilitating students in group learning is the TGT type of cooperative learning model. The TGT type of cooperative learning model is one type of cooperative learning that places students in study groups consisting of 5 to 6 students who have different abilities, genders, and syllables or races. In group work, the teacher gives worksheets to each group. The tasks given are done together with group members. If any of the group members do not understand the given task, then the other group members are responsible for providing answers or explaining them, before asking the question to the teacher [4].

In TGT, one group consists of 3 students who have heterogeneous abilities (low, medium, and high). The results of learning mathematics with games designed in this model allow students to learn more relaxed in addition to fostering responsibility, cooperation, healthy competition, and learning engagement. There are 5 main components in TGT, namely presentations in class, teams (groups), games (games), tournaments, and team recognition [5].

The purpose of the TGT type of cooperative learning model is to increase good cooperation between students in solving existing problems by freeing these students to express their opinions and ideas, helping students to increase positive attitudes in learning mathematics, making students learn more active and get more achievements because they work together and are responsible for making the group the best group [6].

The advantages of TGT type cooperative learning are broadening students' horizons, developing attitudes and behaviors of respect for others, active involvement of students in teaching and learning, students become enthusiastic in learning, knowledge gained by students is not solely from the teacher, but also through construction. by the students themselves [7].

\section{RESEARCH METHODS}

The type of research used in this study is experimental, with a post-test only non-equivalent control group design. Experimental research can be carried out as a research method used to find the effect of certain treatments on others under controlled conditions [8].

The population in this study were all class VIII. Population is also not just the number that exists in the object/subject being studied, but includes all the characteristics/properties possessed by the subject or object [9].

The sample in this study was class VIII-A as the experimental class and class VIII-B as the control class. The sample is part or representative of the population under study. The sampling technique used in this study is probability sampling technique [10].

The probability sampling technique used is cluster sampling. Cluster sampling is data collection from clusters which is done randomly. In cluster random sampling, random sampling is done by randomization is the group and not individually [11].

Data collection techniques and instruments used in this study were tests and observations. According to Sudijono [12], a test is a task or a series of tasks given to an individual or group of individuals, with the intention of comparing their skills with one another. Meanwhile, according to Sugiyono [13], in using the observation method the most effective way is to complete it with an observation format or blank as an instrument. The compiled format contains items about the events or behaviors that are described as going to happen.

The data analysis technique in this research is the analysis of the t-test type separated variance $t=\frac{\overline{x_{1}}-\bar{x}_{2}}{\sqrt{\frac{s_{1}^{2}}{n_{1}}+\frac{s_{2}{ }^{2}}{n_{2}}}}$ with description, $t$ : value of $\mathrm{t}$ count, $\bar{x}_{1}$ : the average value of the post test in the experimental class, $\quad \bar{x}_{2}$ : the average value of the post test in the control class, $n_{1}$ : many students in the experimental class, $n_{2}:$ many students in the control class, $s_{1}{ }^{2}$ : post test variance in the experimental class, ${s_{2}}^{2}$ : post test variance in the control class [14]. 
Separated variance t-test was conducted to determine the significant difference between the two samples being compared and to obtain research results with the same initial ability and to determine the effect of the applied learning model. However, before testing the hypothesis, the normality test and homogeneity test were first carried out.

To find out the influence of the TGT type cooperative learning model on the mathematics learning outcomes of class VIII students, it can be done using Effect Size calculations. To calculate the effect size on the t-test, Cohen's formula is used, namely, $d=\frac{\bar{x}_{t}-\bar{x}_{c}}{s_{\text {pooled }}}$ with description, $d$ : cohen's $d$ effect size (big influence), $\bar{x}_{t}$ : experimental class average, $\bar{x}_{c}$ : control class average, $s_{\text {pooled }}=$ combined variance [15].

\section{RESULTS AND DISCUSSION}

1. Normality test

In this study, normality testing was carried out using the Liliefors test. After the calculations were carried out, the results were obtained in Table 2 below.

Based on Table 2, it was found that H_o was accepted, meaning that the post-test score data for students in the experimental class and control class came from a normally distributed population.

2. Homogeneity Test

In this study, homogeneity testing was carried out using the Bartlett test. After calculating the results obtained $x^{2}$ count as big as 3,472, $x^{2}$ table as big as 3,841 , with the test decision that $x^{2}$ count on all data is less than the value of $x^{2}$ table. So $H_{0}$ is accepted, it means that the post-test value of the experimental class and the control class has a homogeneous variance.

2. t-test

After performing the normality test and homogeneity test as a test of requirements, then a hypothesis test was carried out using the separated variance type t-test. After calculating the results obtained in Table 3 below.

Tabel 3 The result of t-test

\begin{tabular}{cccccccc}
\hline $\begin{array}{c}\text { Class } \\
\text { sample }\end{array}$ & $\mathrm{N}$ & mean & Var & $t_{\text {count }}$ & $t_{\text {table }}$ & Sig & conclution \\
\hline VIII-A & 31 & 75,45 & 118,856 & 6,995 & 2,00 & 0,05 & \multirow{2}{*}{$H_{0}$ ditolak } \\
\hline VIII-B & 31 & 51,77 & 236,247 & 3 & 03 & 0,05 & \\
\hline
\end{tabular}

Based on Table 3, it can be seen that the average similarity test results obtained the value of $t_{\text {hitung }}>t_{\text {tabel }}$ so that $H_{0}$ was rejected, it means that the average class taught by TGT cooperative learning model and direct learning is not the same. b. Test Effect Size

To find out how much influence the TGT type of cooperative learning model has on students' mathematics learning outcomes, it can be done by using effect size calculations with Cohen's formula obtained data $n_{1}=31, n_{2}=32, s_{1}{ }^{2}=118,856$, $s_{2}{ }^{2}=236,247, \quad S_{\text {pooled }}=13,108$ and $d=1,81$, included in the high category. This means that the application of cooperative learning type TGT has a high influence on the learning outcomes of class VIII students. This is in accordance with the opinion of Yuliana [16], that from the calculation of the effect size, an ES of 0.86 is obtained and is categorized as an effect size with a high criterion, namely ES > 0.8. Based on the calculation of the effect size, it can be concluded that the application of the team games tournament type cooperative model has a major influence on the high student learning outcomes in learning mathematics in class IV, State Elementary School 11 Pontianak City.

Before being given to students, the test questions were first validated by the validator. This is done to provide input and advice for researchers from experts on the instrument, so that the instrument can be used properly. From the validation results obtained several suggestions by the validators on the instruments used in the study, namely a) post test questions, can be used with minor revisions, b) lesson plans, complete writing learning materials and separate learning materials at each meeting 1-4 and can be used with minor revisions, c) LKPD can be used with minor revisions.

In general, the steps for implementing learning in the control class include: (1) conveying learning objectives and preparing students, (2) demonstrating knowledge or skills, (3) guiding training, (4) checking understanding and providing feedback, (5 ) provide opportunities for advanced training and application [17].

Then, the steps for implementing learning in the experimental class include: (1) preliminary activities by providing apperception, (2) core activities using the Cooperative learning model syntax of Teams Games Tournament (TGT), (3) closing activities, namely concluding learning [18].

In the introductory activity, the teacher conveys greetings, checks attendance, conveys material and learning objectives, and students are given motivation and apperception by asking material about the system of linear equations of two variables related to everyday life.

After the preliminary activities, the main activities are continued. Before starting the lesson, the teacher explains the learning steps that will be 
used so that students are better prepared to follow the lesson. Then the teacher forms groups where the number of members in each group is 5-6 people. This is in accordance with Hartadji's opinion [19], that groups are formed from students who have high, medium and low abilities, and if possible group members come from different races, cultures, ethnicities and genders.

Furthermore, students are distributed worksheets (LKS), where these worksheets are designed and compiled to find mathematical formulas or concepts or principles that are the objectives of learning and can improve students' mathematics learning outcomes. The teacher guides the discussion by going around to provide direction or explanation for students who have difficulty. This is in accordance with the opinion of Rachmat [20], that the purpose of giving LKS is that students more easily understand the material being studied based on the guidelines in the LKS and the teacher has the opportunity to provoke students to be actively involved in the material discussed.

Group activities went smoothly, many students asked the teacher and their friends to get as much information as possible. Group activities ended with presentations to communicate the results of their discussions to other groups. Then the teacher gives an opportunity for each group to present the results of their discussion. In addition, in the presentation activity the groups that did not present the results of their discussions gave their input or opinions about the results of the presentation. This is in accordance with the opinion of Darmayanti [21], that the purpose of grouping students is so that students can build concepts of knowledge through their personal experiences and discussions with their groupmates.

After the presentation, the students were directed to the game to test their knowledge regarding the presentation of material and group learning activities. Students are placed on tournament tables each tournament table consists of 3 students representing their team or group. Then the teacher directs students to choose numbered cards and tries to answer questions that match the number to get a score where the scores are collected by students for the tournament. This is in accordance with Wulandari's opinion [22], that the purpose of holding games is to test students' knowledge. The game is done by students answering questions about the system of linear equations in two variables from numbered question cards. This game is carried out after group discussion. The existence of competition in this game will make students more motivated to study seriously to win the game, so that student learning motivation will also increase. Then the teacher conducts tournament activities, this tournament activity is carried out at the end of the two-variable linear equation system sub material. After that, the teacher divides students into tournament tables based on their respective superiors seen from the scores that have been obtained in the game and gives tournament questions to each tournament group that has been formed. The teacher gives directions to students about tournament procedures and monitors the course of the ongoing tournament. Then the teacher announces the winning group based on the score obtained and gives an award to the winning group. This is in accordance with the opinion of Wartono et al [23], that this tournament makes it possible for students of all levels to contribute maximum scores for their group if they try their best and this tournament can also act as a review of subject matter.

With this game tournament activity, it can help students better understand the material learned from the results of group discussions and students can practice solving problems using questions that are read during the tournament. In addition, teamwork also gives them a sense of responsibility for their own learning and for their group friends. If they want to get group awards, then they have to compete healthy with other groups. Each group must understand the material provided and actively ask and give the correct answer. This is in accordance with Yanti's opinion [24], that by applying the TGT type of cooperative learning model (Team Games Tournament) it is expected to be able to make students more enthusiastic about learning and not feel bored, because the TGT learning model contains games/tournaments in the classroom where The winner of this tournament will be given an award, so students will be encouraged to be the best.

As a closing activity, students and teachers both conclude the lesson. At the first meeting the teacher and students were seen to be active in the learning process, at the second meeting the teacher and students were very active in the learning process, the third and fourth meetings were very active teachers and students were active in the learning process.

By applying the Teams Games Tournament (TGT) cooperative learning model, students in the experimental class are required to be more responsible, cooperate in solving problems of understanding the material and compete in tournament activities with their team in a fun way, so that students do not feel bored and bored in carrying out the learning process. . This is in accordance with Hikmah's opinion [25], that learning by applying the TGT type cooperative model makes students more flexible in discussing, so that more ideas arise and for students who are reluctant to ask directly to the teacher, they can ask friends in their group. Through discussion, there are more opportunities to ask questions, so students' understanding will be better so that their learning outcomes are also better. As well as the opinion of 
Nur et al [26], who suggested several benefits that can be obtained by students after implementing cooperative learning, namely a higher sense of selfesteem, improved attendance, better understanding of subject matter and greater motivation to learn.

\section{CONCLUSIONS}

Conclusions

Based on the results of the post-test t-test with an alpha of 0.05 , it was found that there was a significant effect on the application of the Teams Games Tournament (TGT) type of cooperative learning model on students' mathematics learning outcomes. By using the effect size test, the application of the Teams Games Tournament (TGT) type of cooperative learning model provides a high influence/contribution to student learning outcomes.

\section{Suggestions}

For teachers, especially at SMPN 13 Mataram, it should be an alternative learning model for the Teams Games Tournament (TGT) cooperative model as an alternative for further mathematics learning.

Things that must be considered in applying the Teams Games Tournament (TGT) type of cooperative learning model. The selected game should be interesting at every meeting. After holding a tournament or game, students should be given time to discuss and given an answer key so that students can correct their mistakes.

\section{REFERENCES}

[1] Depdiknas. (2003). Kumpulan Pedoman Kurikulum 2004. Jakarta: Depdiknas.

[2] Kemendikbud. (2013). Kerangka Dasar dan Struktur Kurikulum 2013. Jakarta: Kemendikbud.

[3] Soedjadi, R. (2000). Kiat Pendidikan Matematika di Indonesia; Konstatasi Keadaan Masa Kini Menuju Harapan Masa Depan. Jakarta: Dirjen Dikti. Depdiknas.

[4] Gora, W \& Sunarto. (2010). Pakematik Strategi Pembelajaran Inovatif Berbasis TIK. Jakarta: PT Elex Media Komputindo.

[5] Ernawati, T. (2018). Pengaruh Model Pembelajaran Kooperatif Tipe Teams Games Tournament (TGT) Terhadap Hasil Belajar IPA Siswa Kelas VIII SMP Ditinjau Dari Kerjasama Siswa.J. Pijar MIPA, Vol. XIII No.1, 82-85.

[6] Daryanto. (2014). Pendekatan Pembelajaran Saintifik Kurikulum 2013. Yogyakarta: Gava Media.

[7] Priansa, DJ. (2017). Pengembangan Strategi \& Model Pembelajaran-Inovatif, Kreatif, Dan Prestatif Dalam Memahami Peserta Didik. Bandung: Pustaka Setia.
[8] Sugiyono. (2013). Metode penelitian pendidikan. Bandung: Alfabeta.

[9] Sugiyono. (2014). Metode Penelitian Kombinasi (Mixed Methods). Bandung: Alfabeta.

[10] Arikunto, S. (2010). Prosedur Penelitian Suatu Pendekatan Praktik. Jakarta: Rineka Cipta.

[11] Hamdi, S. R. (2018). Pengaruh Model Pembelajaran Kooperatif Tipe Teams Games Tournament (TGT) Terhadap Hasil Belajar Matematika Siswa Kelas VIII SMPN 8 Mataram Pada Materi Pola Bilangan dan Barisan

[12] Sudijono, A. (2015). Pengantar Evaluasi Pendidikan. Jakarta: PT. Raja Grafindo Persada.

[13] Sugiyono. (2010). Metode Penelitian Pendidikan (Pendekatan Kuantitatif, Kualitatif dan $R \& D)$. Bandung: Alfabeta.

[14] Sundayana, R. (2016). Statistika Penelitian Pendidikan. Bandung: Alfaberta.

[15] Becker, L, A. (2000). Effect Size Measures For Two Independen Groups. Journal: Effect Size.

[16] Yuliana. (2012). Pengaruh Penerapan TGT Terhadap Hasil Belajar Pada Pembelajaran Matematika Kelas IV SDN 11 Ponkot. Pontianak: Universitas Tanjung Pura.

[17] Zainal, Aswan. (2002). Strategi Belajar Mengajar. Jakarta: Asdi Mahasatya.

[18] Shoimin, Aris. (2017). 68 Model Pembelajaran Inovatif dalam Kurikulum 2013. Depok: Ar-Ruzz Media.

[19] Hartadji, Nursyafi'i. (2001). Pengembangan dan Uji Coba Perangkat Contextual Teaching and Learning. Jakarta: Depdiknas.

[20] Rachmat. (2003). Alternatif Pembelajaran Matematika Dalam Implementasi Kurikulum Berbasis Kompetensi. Bandung: FMIPAUPI.

[21] Darmayanti, K.A. (2016). Pengaruh Model TGT Terhadap Hasil Belajar Matematika Dengan Kovariabel Kemampuan Numerik Pada Siswa Kelas V. e-Journal PGSD Universitas Pendidikan Ganesha. Jurusan PGSD Vol: 4 No: 1 Halaman: 17-22.

[22] Wulandari, DAK. (2013). Keefektifan Model Pembelajaran Kooperatif Tipe Teams Games Tournament Pada Motivasi Belajar Dan Kemampuan Komunikasi Matematika. Skripsi. Semarang: Univeritas Negeri Semarang.

[23] Wartono, dkk. 2004. Materi Pelatihan Terintegrasi Sains (Buku 4). Jakarta: Proyek PSPP Depdiknas.

[24] Yanti, A.R. 2014. Pengaruh Pembelajaran Kooperatif Tipe Teams Games Tournament Terhadap Hasil Belajar Matematika Di Kelas VIII SMPN 2 Bukit Tinggi Tahun Pelajaran 
J. Pijar MIPA, Vol. 16 No.5, November 2021: 583-588

2013/2014.Jurnal Pendidikan Matematika, Vol.3 No. Hal. 1-5.

[25] Hikmah, Msy. 2018. Penerapan Model Pembelajaran Team Games Tournament (TGT) Terhadap Motivasi Dan Hasil Belajar Peserta Didik Pada Materi Dunia Hewan Kelas $X$ di SMA Unggul Negeri 8 Palembang. 46 Jurnal Pembelajaran Biologi, Volume 5, Nomor 1.

[26] Nur, Muhammad, dkk. 2001. Pembelajaran Kooperatif Dalam Kelas IPA. Surabaya: Universitas Negeri. 